\title{
The role of TRPP2 in agonist-induced gallbladder smooth muscle contraction
}

\author{
Xingguo Zhong ${ }^{1 \dagger}$, Jie Fu ${ }^{2 \dagger}$, Kai Song ${ }^{2 \dagger}$, Nairui Xue ${ }^{2}$, Renhua Gong ${ }^{1}$, Dengqun Sun ${ }^{1}$, \\ Huilai Luo ${ }^{1}$, Wenzhu $\mathrm{He}^{2}$, Xiang $\mathrm{Pan}^{2}$, Bing Shen ${ }^{2,3^{*}} \&$ Juan $\mathrm{Du}^{2 *}$ \\ ${ }^{1}$ Department of Surgery, Anhui Provincial Corps Hospital of Chinese People's Armed Police Force, Heifei 230041, China; \\ ${ }^{2}$ Department of Physiology, Anhui Medical University, Hefei 230032, China; \\ ${ }^{3}$ Central Laboratory of Molecular And Cellular Biology of Basic Medical College, Anhui Medical University, Hefei 230032, China
}

Received July 26, 2015; accepted September 1, 2015; published online December 10, 2015

\begin{abstract}
TRPP2 channel protein belongs to the superfamily of transient receptor potential (TRP) channels and is widely expressed in various tissues, including smooth muscle in digestive gut. Accumulating evidence has demonstrated that TRPP2 can mediate $\mathrm{Ca}^{2+}$ release from $\mathrm{Ca}^{2+}$ stores. However, the functional role of TRPP2 in gallbladder smooth muscle contraction still remains unclear. In this study, we used $\mathrm{Ca}^{2+}$ imaging and tension measurements to test agonist-induced intracellular $\mathrm{Ca}^{2+}$ concentration increase and smooth muscle contraction of guinea pig gallbladder, respectively. When TRPP2 protein was knocked down in gallbladder muscle strips from guinea pig, carbachol $(\mathrm{CCh})$-evoked $\mathrm{Ca}^{2+}$ release and extracellular $\mathrm{Ca}^{2+}$ influx were reduced significantly, and gallbladder contractions induced by endothelin 1 and cholecystokinin were suppressed markedly as well. CCh-induced gallbladder contraction was markedly suppressed by pretreatment with U73122, which inhibits phospholipase C to terminate inositol 1,4,5-trisphosphate receptor $\left(\mathrm{IP}_{3}\right)$ production, and 2-aminoethoxydiphenyl borate (2APB), which inhibits $\mathrm{IP}_{3}$ recepor $\left(\mathrm{IP}_{3} \mathrm{R}\right)$ to abolish $\mathrm{IP}_{3} \mathrm{R}$-mediated $\mathrm{Ca}^{2+}$ release. To confirm the role of $\mathrm{Ca}^{2+}$ release in CCh-induced gallbladder contraction, we used thapsigargin (TG)-to deplete $\mathrm{Ca}^{2+}$ stores via inhibiting sarco/endoplasmic reticulum $\mathrm{Ca}^{2+}$-ATPase and eliminate the role of store-operated $\mathrm{Ca}^{2+}$ entry on the CCh-induced gallbladder contraction. Preincubation with $2 \mu \mathrm{mol} \mathrm{L}{ }^{-1} \mathrm{TG}$ significantly decreased the CCh-induced gallbladder contraction. In addition, pretreatments with U73122, 2APB or TG abolished the difference of the $\mathrm{CCh}$-induced gallbladder contraction between TRPP2 knockdown and control groups. We conclude that TRPP2 mediates $\mathrm{Ca}^{2+}$ release from intracellular $\mathrm{Ca}^{2+}$ stores, and has an essential role in agonist-induced gallbladder muscle contraction.
\end{abstract}

TRP channel, TRPP2, contraction, gallbladder smooth muscle, $\mathrm{Ca}^{2+}$ store, inositol 1,4,5-trisphosphate receptor

Citation: Zhong, X., Fu, J., Kai, S., Xue, N., Gong, R., Sun, D., Luo, H., He, W., Pan, X., Shen, B., Du, J. (2016). The role of TRPP2 in agonist-induced gallbladder smooth muscle contraction. Sci China Life Sci 59, 409-416. doi: 10.1007/s11427-015-4958-5

\section{INTRODUCTION}

The transient receptor potential (TRP) protein superfamily consists of a diverse group of nonselective cation channels (Pan et al., 2011; Wu et al., 2010). The majority of TRP

$\dagger$ Contributed equally to this work.

*Corresponding author (email: dujuan@ahmu.edu.cn; shenbing@ahmu.edu.cn) channels displays a $\mathrm{Ca}^{2+}$-permeable feature, and thus they usually mediate $\mathrm{Ca}^{2+}$ signaling and exert particular importance in physiological sensory responses to temperature, light, smell, taste, and mechanical and painful chemical stimuli (Earley and Brayden, 2010; Venkatachalam and Montell, 2007; Vennekens et al., 2012; Zhang and Gutterman, 2011). In addition, the dysfunction of TRP channels has been linked with diverse human diseases, such 
as type IV mucolipidosis (ML4) caused by loss-of-function mutations of human transient receptor potential mucolipin family member 1 (TRPML1), autosomal dominant polycystic kidney disease caused by mutations in the Polycystic kidney disease 2 (PKD2) or PKD1 gene and tumor growth and metastasis caused by transient receptor potential melastatine family member 8 (TRPM8) (Cheng et al., 2010; Grantham et al., 2011; Moran et al., 2011; Nilius and Owsianik, 2010).

The TRPP2 protein, a member of the TRP protein superfamily, is encoded by the PKD2 gene (Mochizuki et al., 1996). TRPP2 channels are composed of four subunits, and each subunit contains six transmembrane segments (S1-S6) with a putative pore-forming region between S5 and S6 (Montell, 2005). Members from different TRP subfamilies can form heteromultimers with distinct functions. For example, TRPP2 interacts with PKD1 to form a heteromultimeric ion channel complex (Hanaoka et al., 2000; Tsiokas et al., 1997). Further, TRPP2 and transient receptor potential vanilloid family member 4 (TRPV4) can form a polymodal sensory channel complex, and TRPP2 and transient receptor potential canonical member 1 (TRPC1) assemble to form a receptor-operated channel (Bai et al., 2008; Kottgen et al., 2008). TRPP2 channels are widely distributed in the plasma membrane and endoplasmic reticulum (ER) (Tsiokas, 2009). TRPP2 can not only mediate intracellular $\mathrm{Ca}^{2+}$ release, but also regulate extracellular $\mathrm{Ca}^{2+}$ influx to enhance intracellular $\mathrm{Ca}^{2+}$ concentration $\left(\left[\mathrm{Ca}^{2+}\right]_{\mathrm{i}}\right)$ (Gonzalez-Perrett et al., 2001; Koulen et al., 2002). In TRPP2-defective cholangiocytes, cytoplasmic and ER $\mathrm{Ca}^{2+}$ levels are lower and store-operated $\mathrm{Ca}^{2+}$ entry (SOCE) is drastically decreased (Spirli et al., 2012). In vascular smooth muscle cells, the opening of TRPP2 channels causes the elevation of $\left[\mathrm{Ca}^{2+}\right]_{i}$, which contributes to the contraction of smooth muscle cells (Zhao et al., 2015).

Cholecystokinin (CCK) and endothelin-1 (ET-1) receptor play an important role in gallbladder contraction. CCK receptor dysfunction may result in the impairment of smooth muscle contractility (Suzuki et al., 2001). As members of G protein-coupled receptor (GPCR) superfamilies, CCK and ET-1 receptors can activate phospholipase C (PLC) and lead the hydrolysis of phosphatidylinositol 4, 5-bisphosphate, producing both diacylglycerol and inositol 1,4,5-trisphosphate $\left(\mathrm{IP}_{3}\right)$ (Noble et al., 1999). Through the interaction between $\mathrm{IP}_{3}$ receptor $\left(\mathrm{IP}_{3} \mathrm{R}\right)$ and TRPP2 in the ER membrane, the activation of $\mathrm{IP}_{3} \mathrm{R}$ increases local cytosolic $\mathrm{Ca}^{2+}$ concentration, which may activate TRPP2 to evoke further $\mathrm{Ca}^{2+}$ release (Li et al., 2005; Sammels et al., 2010). $\mathrm{Ca}^{2+}$ store depletion will then initiate SOCE. The increase of $\left[\mathrm{Ca}^{2+}\right]_{\mathrm{i}}$ is a pivotal event to cause the smooth muscle contraction in response to agonists (Karaki et al., 1997). Therefore, TRPP2 channels may play an important role in maintaining gallbladder smooth muscle tension.
In the present study, we identified the physiological function of TRPP2 in gallbladder smooth muscle contraction. Our results show that TRPP2 is important in agonist-induced gallbladder smooth muscle contraction.

\section{RESULTS}

\section{The role of TRPP2 in agonist-induced $\left[\mathrm{Ca}^{2+}\right]_{i}$ increase in gallbladder smooth muscle}

To explore the function of TRPP2 in agonist-induced $\left[\mathrm{Ca}^{2+}\right]_{\mathrm{i}}$ increase, we employed RNA interface technique. Several specific TRPP2 siRNAs were designed and transfected into guinea pig gallbladder muscle strips via primary culture. Immunoblotting data confirmed that TRPP2 siRNAs 1077 and 840 successfully suppressed TRPP2 expression in guinea pig gallbladder muscle (Figure 1A). We subsequently used both 1077 and 840 TRPP2 siRNAs to knock down TRPP2 and examine the $\left[\mathrm{Ca}^{2+}\right]_{i}$ change in guinea pig gallbladder muscle strips. Gallbladder smooth muscle strips were treated with $100 \mu \mathrm{mol} \mathrm{L}{ }^{-1} \mathrm{CCh}$ in $\mathrm{Ca}^{2+}$-free saline solution for $10 \mathrm{~min}$, after which $2.5 \mathrm{mmol} \mathrm{L}^{-1} \mathrm{Ca}^{2+}$ was added to the extracellular solution. Knockdown of TRPP2 significantly reduced $\mathrm{CCh}$-evoked $\mathrm{Ca}^{2+}$ release compared with the treatment of scrambled siRNA. The extracellular $\mathrm{Ca}^{2+}$ influx was also significantly reduced (Figure 1B-D).

\section{The role of TRPP2 in agonist-induced contraction in gallbladder smooth muscle}

$\left[\mathrm{Ca}^{2+}\right]_{\mathrm{i}}$ rise is an important event in causing smooth muscle contraction in response to agonists (Karaki et al., 1997). Since TRPP2 contributed to the CCh-evoked $\left[\mathrm{Ca}^{2+}\right]_{\mathrm{i}}$ rise in gallbladder smooth muscle, we further examined the function of TRPP2 in agonist-induced gallbladder contraction. In tension measurement experiments, CCh, ET-1 and CCK-induced concentration-dependent contractions were significantly decreased in groups transfected with TRPP2 siRNAs 1077 or 840 (Figure 2).

\section{The role of $\mathrm{Ca}^{2+}$ store release in $\mathrm{CCh}$-induced gallblad- der contraction}

The activation of GPCRs can produce $\mathrm{IP}_{3}$, evoking the $\mathrm{Ca}^{2+}$ release, which in turn initiates SOCE to contract smooth muscle. To examine this signaling pathway, we used U73122, which inhibits PLC to terminate the $\mathrm{IP}_{3}$ production, and $2 \mathrm{APB}$, which inhibits $\mathrm{IP}_{3} \mathrm{R}$ to abolish $\mathrm{IP}_{3} \mathrm{R}$-mediated $\mathrm{Ca}^{2+}$ release (Maruyama et al., 1997). The results indicated that pretreatment with $100 \mu \mathrm{mol} \mathrm{L}^{-1} 2 \mathrm{APB}$ or $10 \mu \mathrm{mol} \mathrm{L}{ }^{-1} \mathrm{U} 73122$ markedly suppressed CCh-induced guinea pig gallbladder contraction. To confirm the role of $\mathrm{Ca}^{2+}$ release from $\mathrm{Ca}^{2+}$ store in $\mathrm{CCh}$-induced gallbladder contraction, we used TG to deplete the $\mathrm{Ca}^{2+}$ stores via inhibiting sarco/endoplasmic reticulum $\mathrm{Ca}^{2+}$-ATPase (SERCA) (Bian et al., 1991). Figure 3A shows that preincubation with $2 \mu \mathrm{mol} \mathrm{L} \mathrm{L}^{-1}$ TG for $10 \mathrm{~min}$ significantly de 

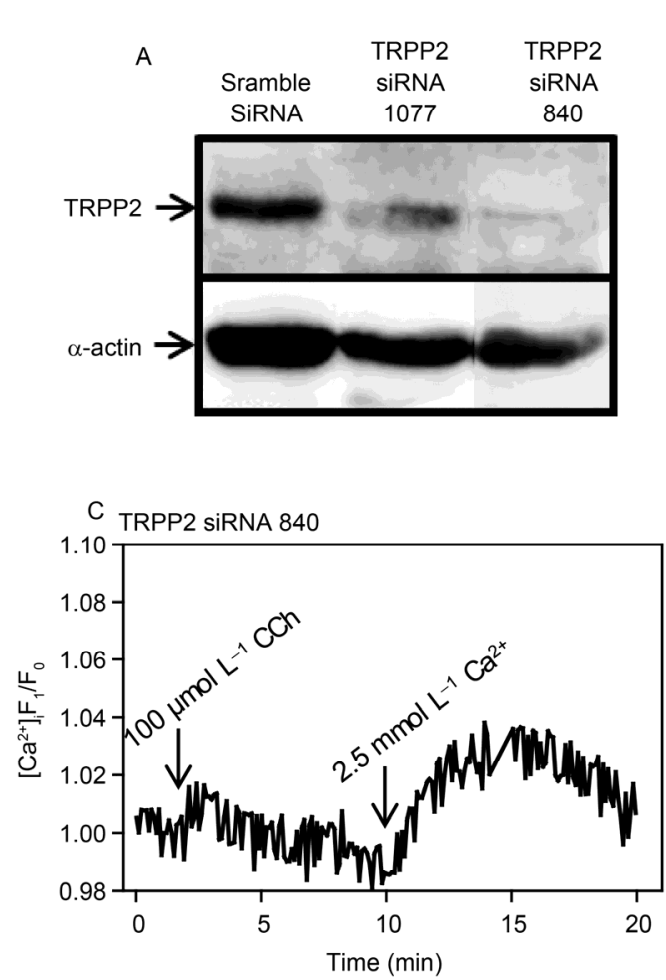
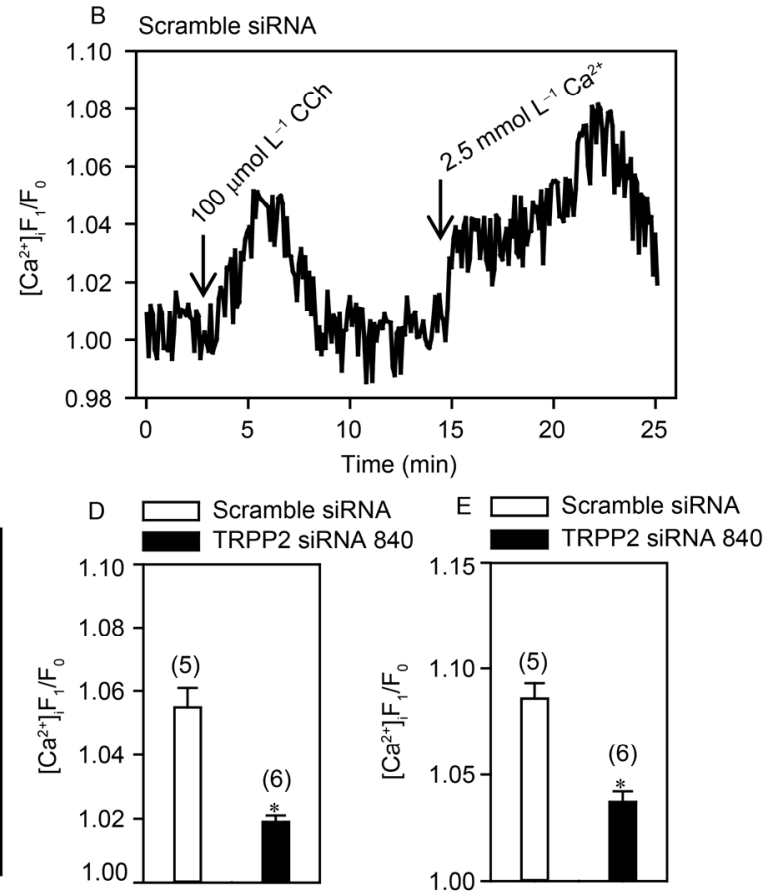

Figure 1 Role of TRPP2 in agonist-induced intracellular $\mathrm{Ca}^{2+}$ concentration $\left(\left[\mathrm{Ca}^{2+}\right]_{\mathrm{i}}\right)$ increase of gallbladder smooth muscle. A, Representative blots showing TRPP2 expression level in scrambled siRNA (control), TRPP2 siRNA 1077 and TRPP2 siRNA 840 treatments. B and C, Representative traces showing $100 \mu \mathrm{mol} \mathrm{L}{ }^{-1}$ carbachol $(\mathrm{CCh})$-evoked $\mathrm{Ca}^{2+}$ release in $\mathrm{Ca}^{2+}$-free saline solution and $2.5 \mathrm{mmol} \mathrm{L}^{-1} \mathrm{Ca}^{2+}$ application-induced $\left[\mathrm{Ca}{ }^{2+}\right]_{\mathrm{i}}$ rise in guinea pig gallbladder smooth muscle strips pretreated with scrambled siRNA (B) or TRPP2 siRNA 840 (C). D and E, Summary of data showing changes in [Ca $\left.{ }^{2+}\right]_{i}$ rise in response to $\mathrm{CCh}(\mathrm{D})$ and extracellular $\mathrm{Ca}^{2+}$ application (E). Data are shown as $\bar{x} \pm \mathrm{SE}$. $n=5-6$ samples. $*, P<0.05$ compared with scrambled siRNA.

creased gallbladder smooth muscle contraction induced by $\mathrm{CCh}$. However, if the extracellular $\mathrm{Ca}^{2+}$ was removed with $0.2 \mathrm{mmol} \mathrm{L}^{-1}$ ethylene glycol tetraacetic acid (EGTA) $\left(\mathrm{Ca}^{2+}\right.$-free $)$ or voltage-gated $\mathrm{Ca}^{2+}$ channels were inhibited by $1 \mu \mathrm{mol} \mathrm{L} \mathrm{L}^{-1}$ verapamil, the remaining contraction in the presence of TG was significantly decreased further (Figure $3 \mathrm{E})$. In addition, there are no dramatic difference in the remaining CCh-induced contraction in the treatment of TG between $\mathrm{Ca}^{2+}$-free and verapamil treatment (Figure 3E).

\section{The role of TRPP2-mediated $\mathrm{Ca}^{2+}$ release in CCh-induced gallbladder contraction}

$\mathrm{Ca}^{2+}$ release from $\mathrm{IP}_{3} \mathrm{R}$ can potentiate TRPP2 to mediate further $\mathrm{Ca}^{2+}$ release from $\mathrm{Ca}^{2+}$ stores (Katritch et al., 2013; Sammels et al., 2010). Our data also showed that TRPP2 knockdown would inhibit store $\mathrm{Ca}^{2+}$ release and contraction of gallbladder smooth muscle (Figure 1B-D and 2). To further confirm the role of TRPP2 in CCh-induced gallbladder contraction and the signaling pathway, we compared the effects of U73122, 2APB and TG on CCh-induced contraction of guinea pig gallbladder strips in TRPP2 knockdown and scrambled siRNA control groups. Interestingly, preincubation with $10 \mu \mathrm{mol} \mathrm{L}{ }^{-1} \mathrm{U} 73122$ or $100 \mu \mathrm{mol} \mathrm{L}{ }^{-1} 2 \mathrm{APB}$ eliminated the differences in CCh-induced contraction between TRPP2 knockdown and scrambled siRNA control gallbladder strips (Figure 3B-D). These results strongly suggested that TRPP2-mediated $\mathrm{Ca}^{2+}$ release critically participates in agonist-induced gallbladder contraction.

\section{DISCUSSION}

In the present study, we examined the role of TRPP2 in gallbladder smooth muscle contraction. Our major findings include the following. (i) Knockdown of TRPP2 via TRPP2 specific siRNA transfection reduced $\mathrm{Ca}^{2+}$ release as well as extracellular $\mathrm{Ca}^{2+}$ influx. (ii) Knockdown of TRPP2 reduced agonist-induced gallbladder smooth muscle contraction. (iii) U73122, 2APB and TG significantly suppressed the CChinduced gallbladder contraction. (iv) Pretreatment with U73122, 2APB or TG eliminated the difference in gallbladder contraction between TRPP2 knockdown and scrambled siRNA control groups.

As a critical secondary messenger, intracellular $\mathrm{Ca}^{2+}$ is closely related to diverse cellular processes including muscle contraction, cell excitability, motility, apoptosis, and proliferation (Clapham, 2007). The increase of $\left[\mathrm{Ca}^{2+}\right]_{i}$ is a main event that causes smooth muscle contraction. $\mathrm{Ca}^{2+}$ can originate from the extracellular $\mathrm{Ca}^{2+}$ influx through voltage-dependent $\mathrm{Ca}^{2+}$ channels and/or receptor-operated $\mathrm{Ca}^{2+}$ channels, and $\mathrm{Ca}^{2+}$ release from the intracellular $\mathrm{Ca}^{2+}$ stores (Floyd and Wray, 2007; Karaki et al., 1997). Thus, func- 

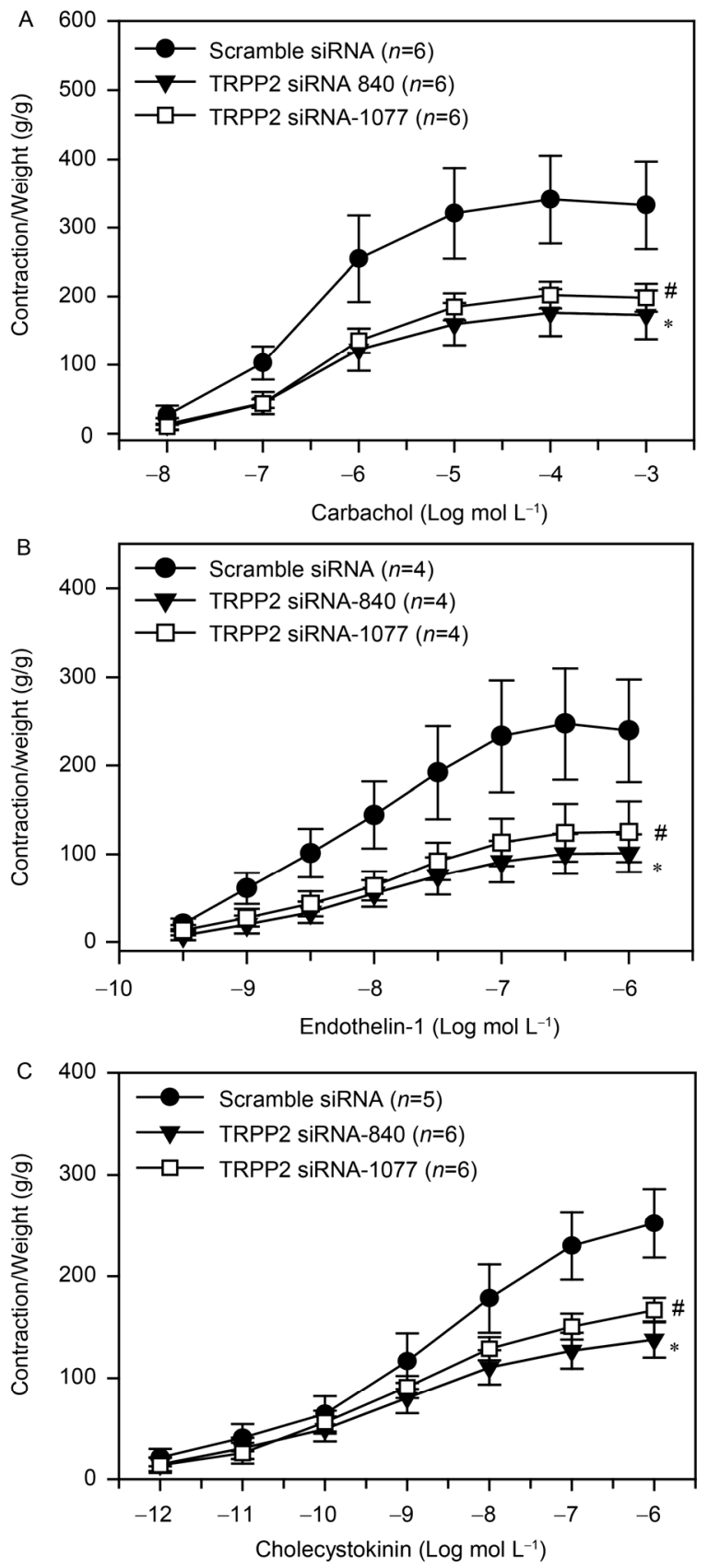

Figure 2 Role of TRPP2 in agonist-induced gallbladder contraction. A-C Summarized data of carbachol (CCh)-, endothelin-1 (ET-1)-, cholecystokinin $(\mathrm{CCK})$-induced contraction of guinea pig gallbladder smooth muscle strips pretreated with scrambled siRNA, TRPP2 siRNA 1077 or TRPP2 siRNA 840 in a concentration-dependent manner. Data are shown as $\bar{x} \pm$ SE. $n=4-6$ samples. $*, P<0.05$ compared with scrambled siRNA.

tional disruption of ion channels that mediate the extracellular $\mathrm{Ca}^{2+}$ influx or the intracellular $\mathrm{Ca}^{2+}$ release will lead to a change of smooth muscle contractile function (Dietrich et al., 2006). In the gallbladder, agonists such as CCK, ET-1 and $\mathrm{CCh}$ induced smooth muscle contraction by an increase in $\left[\mathrm{Ca}^{2+}\right]_{\mathrm{i}}$ comprising $\mathrm{Ca}^{2+}$ release from the intracellular $\mathrm{Ca}^{2+}$ stores and $\mathrm{Ca}^{2+}$ influx from the extracellular solution (Figure 1). GPCRs can increase $\left[\mathrm{Ca}^{2+}\right]_{\mathrm{i}}$ via evoking the $\mathrm{Ca}^{2+}$ release and following SOCE to induce smooth muscle contraction. Activation of muscarinic receptors can couple to PLC activation and increase $\mathrm{IP}_{3}$ production, which in turn releases stored $\mathrm{Ca}^{2+}$ in the cells. However, this $\mathrm{Ca}^{2+}$ release is not the only way to mediate smooth muscle contraction induced by CCh (Frazier et al., 2007). CCh acting on muscarinic receptors not only induces $\mathrm{Ca}^{2+}$ release via PLC-IP pathway, but also increases the resting membrane potential, causing membrane depolarization. Calcium release from the intracellular $\mathrm{Ca}^{2+}$ stores may not directly determine smooth muscle contraction, but indirectly potentiates voltagedependent $\mathrm{Ca}^{2+}$ channels and receptor-operated channel opening to mediate $\mathrm{Ca}^{2+}$ entry (Pacaud and Bolton, 1991). In this study, we examined whether the intracellular $\mathrm{Ca}^{2+}$ release was involved in CCh-induced gallbladder contraction. TG was used to deplete the $\mathrm{Ca}^{2+}$ store via inhibiting SERCA and to evoke SOCE alternatively. The data showed that preincubation with TG decreased gallbladder smooth muscle contraction induced by $\mathrm{CCh}$. But if the extracellular $\mathrm{Ca}^{2+}$ was removed or voltage-gated $\mathrm{Ca}^{2+}$ channels in gallbladder smooth muscle were inhibited by verapamil, the remaining contraction in the treatment of TG was significantly decreased further. Additionally, we did not find the significant difference in the remaining $\mathrm{CCh}$-induced contraction in the treatment of TG between $\mathrm{Ca}^{2+}$ remove and verapamil treatment. TG can deplete the $\mathrm{Ca}^{2+}$ store via $\mathrm{IP}_{3} \mathrm{R}$-dependent and independent pathways (Bian et al., 1991). To further elucidate the role of agonist-induced $\mathrm{Ca}^{2+}$ release from $\mathrm{IP}_{3} \mathrm{R}$ and $\mathrm{PLC}$ activation in $\mathrm{CCh}$-induced gallbladder contraction, we employed the membrane permeable $\mathrm{IP}_{3} \mathrm{R}$ inhibitor $2 \mathrm{APB}$ and the PLC inhibitor U73122 (Maruyama et al., 1997). Our data showed that CChinduced gallbladder contraction was notably suppressed by preincubation with 2 APB or U73122. Therefore, the intracellular $\mathrm{Ca}^{2+}$ release via $\mathrm{IP}_{3} \mathrm{R}$ certainly contributed to $\mathrm{CCh}$-induced gallbladder contraction. When the $\mathrm{Ca}^{2+}$ store was depleted by TG, $\mathrm{Ca}^{2+}$ influx mediated by voltage-gated $\mathrm{Ca}^{2+}$ channels still is involved in CCh-induced the remaining gallbladder contraction.

TRPP2 channels play an essential role in mediating the intracellular $\mathrm{Ca}^{2+}$ release or $\mathrm{Ca}^{2+}$ entry (Gonzalez-Perrett et al., 2001; Koulen et al., 2002). To elucidate the role of TRPP2 in gallbladder smooth muscle, we knocked down the TRPP2 expression using specific siRNA in smooth muscle of guinea pig gallbladder. Interestingly, we found that TRPP2 siRNA not only effectively suppressed TRPP2 protein expression, but also diminished the muscle contractility in tension measurement experiments. With the use of $\mathrm{Ca}^{2+}$ imaging measurements, our results suggested that $\mathrm{Ca}^{2+}$ release was significantly reduced after TRPP2 protein was knocked down. Further, extracellular $\mathrm{Ca}^{2+}$ influx was decreased as well. Therefore, these data indicate that TRPP2 plays a crucial function in agonist-induced gallbladder contraction.

Previous studies showed that TRPP2 opening in the ER 

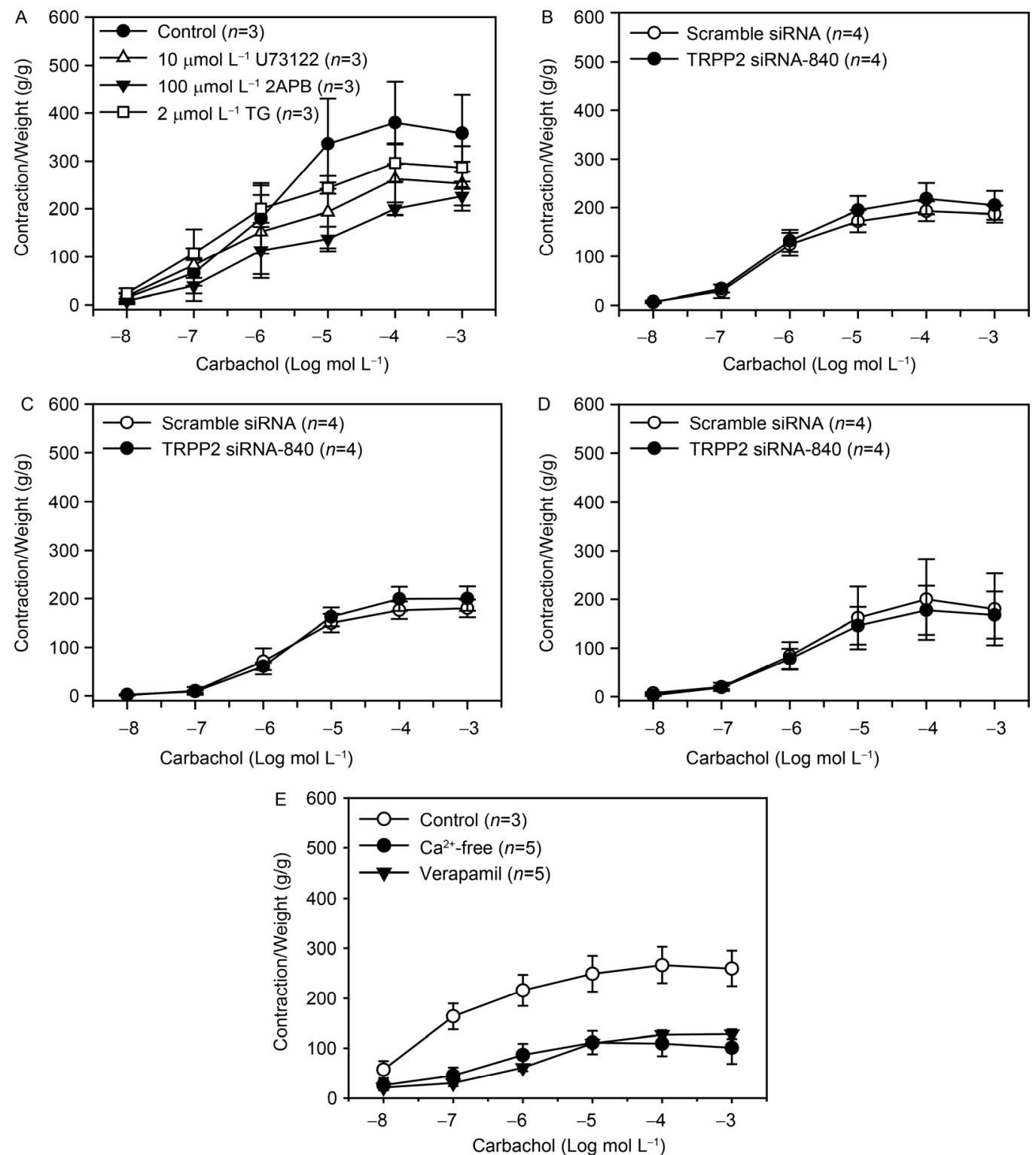

Figure 3 Role of $\mathrm{Ca}^{2+}$ store release in carbachol (CCh)-induced gallbladder contraction. A, Summarized data of CCh-induced contraction of guinea pig gallbladder smooth muscle strips pretreated with $10 \mu \mathrm{mol} \mathrm{L}^{-1} \mathrm{U} 73122,100 \mu \mathrm{mol} \mathrm{L}^{-1}$ 2-aminoethoxydiphenyl borate (2APB) or $2 \mu \mathrm{mol} \mathrm{L} \mathrm{L}^{-1}$ thapsigargin (TG) in a concentration-dependent manner. B-D, After transfection with TRPP2 siRNA840 or scrambled siRNA, guinea pig gallbladder smooth muscle strips were contracted by $100 \mu \mathrm{mol} \mathrm{L}{ }^{-1} \mathrm{CCh}$ with the pretreatment of $10 \mu \mathrm{mol} \mathrm{L}{ }^{-1} \mathrm{U} 73122$ (B), $100 \mu \mathrm{mol} \mathrm{L}{ }^{-1} 2 \mathrm{APB}$ (C) or $2 \mu \mathrm{mol} \mathrm{L}{ }^{-1} \mathrm{TG}$ (D). E, After the treatment with TG alone (Control), or TG in $\mathrm{Ca}^{2+}$-free solution with $0.2 \mathrm{mmol} \mathrm{L}^{-1}$ EGTA ( $\mathrm{Ca}^{2+}$-free), or TG and $1 \mu$ mol L ${ }^{-1}$ verapamil together (Verapamil), $\mathrm{CCh}$-induced contraction of gallbladder smooth muscle strips. Data are shown as $\bar{x} \pm \mathrm{SE} . n=3-5$ samples. ${ }^{*}, P<0.05$ compared with scrambled siRNA or Control.

membrane is dependent on $\mathrm{IP}_{3} \mathrm{R}$ activation ( $\mathrm{Li}$ et al., 2005; Sammels et al., 2010). GPCRs likely play important roles in mediating TRPP2 opening. CCK, ET-1 and CCh can produce $\mathrm{IP}_{3}$ to act on $\mathrm{IP}_{3} \mathrm{R}$ in ER and induce $\left[\mathrm{Ca}^{2+}\right]_{\mathrm{i}}$ increase via a GPCR-PLC-IP 3 pathway (Figure 4 ). In our data, pretreatment with U73122, or 2APB eliminated the difference in CCh-induced gallbladder contraction of TRPP2 knockdown and control groups, which suggested that PLC and $\mathrm{IP}_{3} \mathrm{R}$ should be important molecules involved in TRPP2mediated $\mathrm{Ca}^{2+}$ release. Therefore, after inhibition of this pathway, TRPP2 activation was significantly suppressed.
This is the reason that no difference of gallbladder smooth muscle contraction was observed between control and TRPP2 siRNA transfected groups. Simultaneously, previous studies in other groups showed that TRPP2 also exists in the plasma membrane to mediate $\mathrm{Ca}^{2+}$ influx (Du et al., 2012; Narayanan et al., 2013). To clarify this point, we used TG to deplete $\mathrm{Ca}^{2+}$ store. In TG treatment group, the function of TRPP2 on the plasma membrane still can be remained. However, we found that $\mathrm{Ca}^{2+}$ store depletion induced by TG also removed the difference of CCh-induced contraction between scramble siRNA and TRPP2 siRNA treatments. 


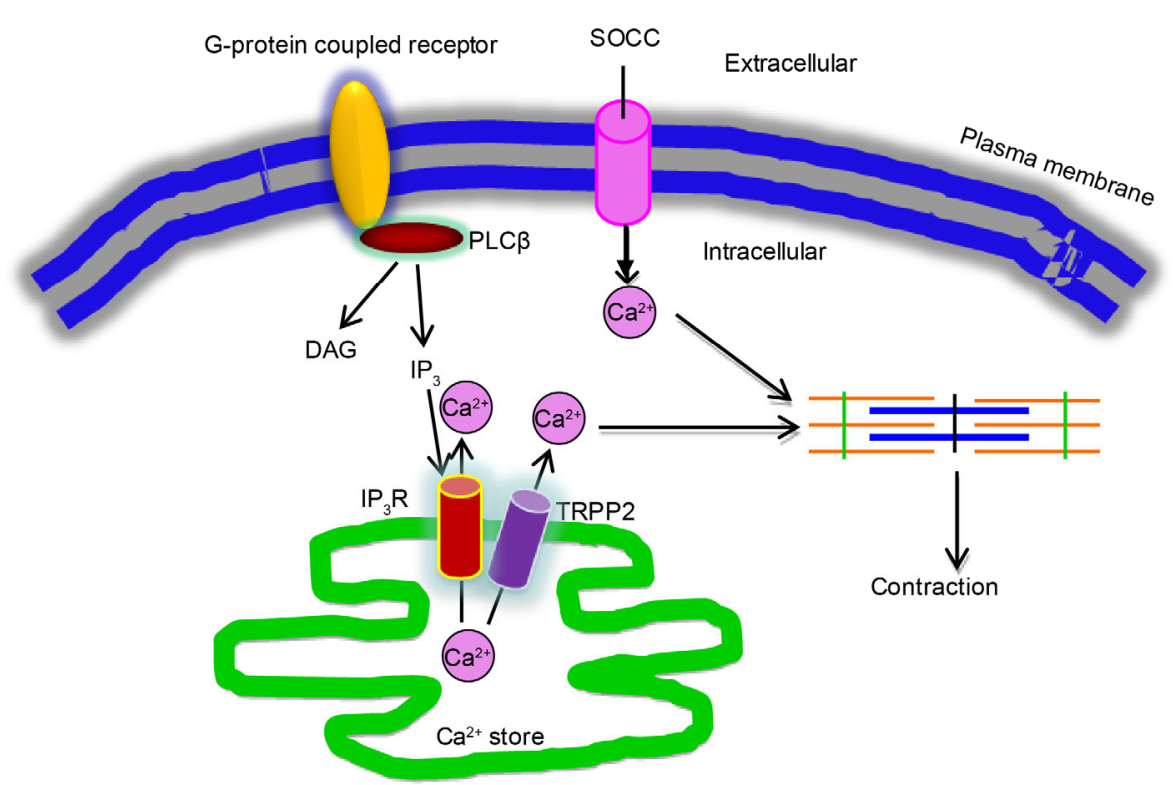

Figure 4 Schematic showing G-protein coupled receptor-TRPP2 signal transduction pathway and relationship with smooth muscle contraction. DAG: diacylglycerol; PLC $\beta$ : phospholipase $\mathrm{C} \beta$; $\mathrm{IP}_{3}$ : inositol trisphosphate; $\mathrm{IP}_{3} \mathrm{R}$ : inositol trisphosphate receptor; SOCC: store-operated Ca ${ }^{2+}$ channel.

This result indicates that TRPP2 on the plasma membrane may not be involved in CCh-induced gallbladder contraction, at least, very weakly.

In addition to TRPP2 channels, many other ion channels mediate $\mathrm{Ca}^{2+}$ homeostasis and contractility in smooth muscle. The stromal interaction molecule 1 (STIM1) and Orai1 channels mediate SOCE in response to the depletion of $\mathrm{Ca}^{2+}$ from intracellular $\mathrm{Ca}^{2+}$ stores (Abdullaev et al., 2008). Physical and functional interaction between TRPC1/TRPC4 channels and STIM1 has been suggested to contribute to SOCE (Sours-Brothers et al., 2009). TRPC4 and TRPC6 channels couple muscarinic receptors to the depolarization of intestinal smooth muscle cells and voltage-activated $\mathrm{Ca}^{2+}$-influx and contraction, and thereby accelerate small intestinal motility in vivo (Tsvilovskyy et al., 2009). Therefore, we cannot exclude the possibility that these components function in the gallbladder smooth muscle contraction as well. In the future, the relationships among these ion channels should be examined to elucidate the detailed mechanisms of gallbladder smooth muscle contraction.

In conclusion, our data suggest that TRPP2-mediated $\mathrm{Ca}^{2+}$ release plays an important role in agonist-induced gallbladder contraction. In addition, GPCRs should be key molecules to initiate TRPP2 opening via the $\mathrm{PLC}^{-\mathrm{IP}_{3}}$ pathway.

\section{MATERIALS AND METHODS}

\section{Materials}

Carbachol (CCh), ET-1,2-aminoethoxydiphenyl borate (2APB) and CCK were purchased from Sigma-Aldrich.
Thapsigargin (TG) and U73122 were obtained from Calbiochem. Anti-TRPP2 primary antibody was from Santa Cruz. TRPP2 specific siRNAs for guinea pig were designed and obtained from Invitrogen. The sequences are as follows: PKD2-1077, 5'-GGCAGCUCAAAGUCAGAAATT-3' and 5'-UUUCUGACUUUGAGCUGCCTT-3'; PKD2-1667, 5'GGGACAGCAAUAGGAAUCATT-3' and 5'-UGAUUCCUAUUGCUGUCCCTT-3'; PKD2-840, 5'-GCUCCCAUGUGUACUACUATT-3' and 5'-UAGUAGUACACAUGGGAGCTT-3'. siRNA delivery was achieved using Lipofectamine RNAiMAX reagent according to the manufacturer's instructions.

\section{Preparation of gallbladder muscle strips}

Male guinea pigs (300-350 g) were obtained from the Animal Center of Anhui Medical University. The guinea pigs were killed by smothering and the gallbladders were removed. The guinea pig was placed in a dish with ice-cold Krebs-Henseleit solution (composition in mmol L ${ }^{-1}: \mathrm{NaCl}$ $118, \mathrm{KCl} 4.7, \mathrm{NaHCO}_{3}$ 25.2, glucose 11.1, $\mathrm{KH}_{2} \mathrm{PO}_{4} 1.2$, $\left.\mathrm{CaCl}_{2} 2.5, \mathrm{MgSO}_{4}\left(7 \mathrm{H}_{2} \mathrm{O}\right) 1.2\right)$ gassed with $95 \% \mathrm{O}_{2}$ and $5 \%$ $\mathrm{CO}_{2}$. After clearing the fat tissue and serosa, the gallbladder was cut along the longitudinal axis into $1.0 \mathrm{~cm} \times 0.3 \mathrm{~cm}$ muscle strips. Each longitudinal muscle strip was suspended in an organ bath containing Krebs solution ( $\mathrm{pH}$ 7.4) gassed with $95 \% \mathrm{O}_{2}$ and $5 \% \mathrm{CO}_{2}$. One end of the strip was fastened to a hook on the bottom of the organ bath using surgical silk suture. The other end was connected to isometric force transducers that were connected to an integrated amplifier and recorder. The isometric tension was recorded and analyzed by a data acquisition and analysis system (BL-420S). 
The bath temperature was maintained at $37^{\circ} \mathrm{C}$. The muscle strip was stretched to $1.0 \mathrm{~g}$ of initial tension and equilibrated for $40 \mathrm{~min}$ with a change of physiological buffer every $15 \mathrm{~min}$ and appropriate adjustment of tension. After an equilibration period, the contractile function of strips was tested twice by replacing the Krebs-Henseleit solution with $80 \mathrm{mmol} \mathrm{L}^{-1} \mathrm{~K}^{+}$solution $\left(80 \mathrm{mmol} \mathrm{L}^{-1}\right.$ high $\mathrm{K}^{+}$solution was prepared by exchanging $\mathrm{NaCl}$ with an equimolar amount of $\mathrm{KCl}$ ), and the second contraction was taken as the reference contraction. The contractile response to $\mathrm{CCh}$ $\left(10^{-8}-10^{-3} \mathrm{~mol} \mathrm{~L}^{-1}\right)$, CCK $\left(10^{-12}-10^{-6} \mathrm{~mol} \mathrm{~L}^{-1}\right)$ and ET-1 $\left(10^{-10}-10^{-6} \mathrm{~mol} \mathrm{~L}^{-1}\right)$ was achieved by cumulatively adding agonists into the bath with or without U73122 (10 $\mu \mathrm{mol}$ $\left.\mathrm{L}^{-1}\right), 2 \mathrm{APB}\left(100 \mu \mathrm{mol} \mathrm{L}{ }^{-1}\right)$ or TG $\left(2 \mu \mathrm{mol} \mathrm{L}^{-1}\right)$ pretreatment for $10 \mathrm{~min}$. For the TRPP2 knockdown group, the gallbladder muscle strips were incubated with TRPP2 siRNA or scrambled control siRNA for 20-24 h.

\section{Western blot analysis}

The proteins were extracted from the lysates of guinea pig gallbladder tissue with detergent extracted buffer containing $20 \mathrm{mmol} \mathrm{L}^{-1}$ Tris- $\mathrm{HCl}$ ( $\mathrm{pH} 7.5$ ), $150 \mathrm{mmol} \mathrm{L}{ }^{-1} \mathrm{NaCl}$, $1 \mathrm{mmol} \mathrm{L}{ }^{-1}$ disodium salt of ethylenediaminetetraacetic acid ( $\mathrm{Na}_{2}$ EDTA), $1 \mathrm{mmol} \mathrm{L}^{-1}$ EGTA, $1 \%$ NP-40, $1 \%$ sodium deoxycholate, and $2.5 \mathrm{mmol} \mathrm{L}^{-1}$ sodium pyrophosphate, plus protease inhibitor cocktail tablets. Protein samples $(100 \mu \mathrm{g})$ were separated on a sodium dodecyl sulfate polyacrylamide gel electrophoresis gel. The polyvinylidene difluoride membrane with transferred proteins was incubated at $4{ }^{\circ} \mathrm{C}$ overnight with anti-TRPP 2 primary antibody (1:200). Immunodetection was performed using horseradish peroxidase-conjugated secondary antibody, followed by processing using an enhanced chemiluminescence (ECL) detection system.

\section{$\left[\mathrm{Ca}^{2+}\right]_{\mathrm{i}}$ measurement}

$\left[\mathrm{Ca}^{2+}\right]_{\mathrm{i}}$ was measured as described previously (Shen et al., 2008). Briefly, the epithelial layer of the isolated guinea pig gallbladder muscle strips were torn off and the tissue was incubated with $10 \mu \mathrm{mol} \mathrm{L}{ }^{-1}$ Fluo-8/AM and $0.02 \%$ pluronic F-127 (Invitrogen) for $1 \mathrm{~h}$ at $37^{\circ} \mathrm{C}$ in Krebs-Henseleit solution. Average $\left[\mathrm{Ca}^{2+}\right]_{\mathrm{i}}$ fluorescence of the smooth muscle layer was measured at $37^{\circ} \mathrm{C}$ in $\mathrm{Ca}^{2+}$-free Krebs-Henseleit solution contained $1 \mu \mathrm{mol} \mathrm{L} \mathrm{L}^{-1}$ verapamil to remove $\mathrm{Ca}^{2+}$ influx by voltage-gated $\mathrm{Ca}^{2+}$ channels and bubbled with

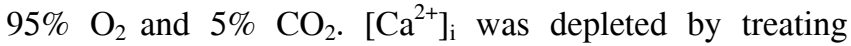

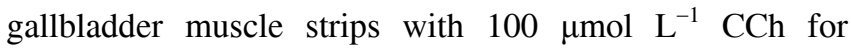
10 min. $\mathrm{Ca}^{2+}$ influx was initiated by applying $2.5 \mathrm{mmol} \mathrm{L}^{-1}$ extracellular $\mathrm{Ca}^{2+} \cdot\left[\mathrm{Ca}^{2+}\right]_{i}$ fluorescence was recorded using fluorescent microscopy. Changes in $\left[\mathrm{Ca}^{2+}\right]_{\mathrm{i}}$ were displayed as the ratio of fluorescence relative to the intensity before the application of $\mathrm{CCh}$ or extracellular $\mathrm{Ca}^{2+}(\mathrm{F} 1 / \mathrm{F} 0)$.

\section{Statistical analysis}

Collected data are presented as $\bar{x} \pm$ SE. The two-tailed paired samples $t$-test was used to compare results in different groups. A value of $P<0.05$ was considered statistically significant.

Compliance and ethics The author(s) declare that they have no conflict of interest.

Acknowledgements This work was supported by Anhui Provincial Natural Science Foundation (1208085MH181, 1108085J11), National Natural Science Foundation of China (81371284), Young Prominent Investigator Supporting Program from Anhui Medical University and National Training Program of Innovation and Entrepreneurship for Undergraduates (201310366012).

Abdullaev, I.F., Bisaillon, J.M., Potier, M., Gonzalez, J.C., Motiani, R.K., and Trebak, M. (2008). Stim1 and Orail mediate CRAC currents and store-operated calcium entry important for endothelial cell proliferation. Circ Res 103, 1289-1299.

Bai, C.X., Giamarchi, A., Rodat-Despoix, L., Padilla, F., Downs, T., Tsiokas, L., and Delmas, P. (2008). Formation of a new receptor-operated channel by heteromeric assembly of TRPP2 and TRPC1 subunits. EMBO Rep 9, 472-479.

Bian, J.H., Ghosh, T.K., Wang, J.C., and Gill, D.L. (1991). Identification of intracellular calcium pools. Selective modification by thapsigargin. J Biol Chem 266, 8801-8806.

Cheng, X., Shen, D., Samie, M., and Xu, H. (2010). Mucolipins: intracellular TRPML1-3 channels. FEBS Lett 584, 2013-2021.

Clapham, D.E. (2007). Calcium signaling. Cell 131, 1047-1058.

Dietrich, A., Chubanov, V., Kalwa, H., Rost, B.R., and Gudermann, T. (2006). Cation channels of the transient receptor potential superfamily: their role in physiological and pathophysiological processes of smooth muscle cells. Pharmacol Ther 112, 744-760.

Du, J., Wong, W.Y., Sun, L., Huang, Y., and Yao, X. (2012). Protein kinase $\mathrm{G}$ inhibits flow-induced $\mathrm{Ca}^{2+}$ entry into collecting duct cells. J Am Soc Nephrol 23, 1172-1180.

Earley, S., and Brayden, J.E. (2010). Transient receptor potential channels and vascular function. Clin Sci (Lond) 119, 19-36.

Floyd, R., and Wray, S. (2007). Calcium transporters and signalling in smooth muscles. Cell Calcium 42, 467-476.

Frazier, E.P., Braverman, A.S., Peters, S.L., Michel, M.C., and Ruggieri, M.R., Sr. (2007). Does phospholipase C mediate muscarinic receptor-induced rat urinary bladder contraction? J Pharmacol Exp Ther 322, 998-1002.

Gonzalez-Perrett, S., Kim, K., Ibarra, C., Damiano, A.E., Zotta, E., Batelli, M., Harris, P.C., Reisin, I.L., Arnaout, M.A., and Cantiello, H.F. (2001). Polycystin-2, the protein mutated in autosomal dominant polycystic kidney disease (ADPKD), is a $\mathrm{Ca}^{2+}$-permeable nonselective cation channel. Proc Natl Acad Sci USA 98, 1182-1187.

Grantham, J.J., Mulamalla, S., and Swenson-Fields, K.I. (2011). Why kidneys fail in autosomal dominant polycystic kidney disease. Nat Rev Nephrol 7, 556-566.

Hanaoka, K., Qian, F., Boletta, A., Bhunia, A.K., Piontek, K., Tsiokas, L., Sukhatme, V.P., Guggino, W.B., and Germino, G.G. (2000). Co-assembly of polycystin-1 and -2 produces unique cation-permeable currents. Nature 408, 990-994.

Karaki, H., Ozaki, H., Hori, M., Mitsui-Saito, M., Amano, K., Harada, K., Miyamoto, S., Nakazawa, H., Won, K.J., and Sato, K. (1997). Calcium movements, distribution, and functions in smooth muscle. Pharmacol Rev 49, 157-230.

Katritch, V., Cherezov, V., and Stevens, R.C. (2013). Structure-function of the $G$ protein-coupled receptor superfamily. Annu Rev Pharmacol Toxicol 53, 531-556. 
Kottgen, M., Buchholz, B., Garcia-Gonzalez, M.A., Kotsis, F., Fu, X., Doerken, M., Boehlke, C., Steffl, D., Tauber, R., Wegierski, T., Nitschke, R., Suzuki, M., Kramer-Zucker, A., Germino, G.G., Watnick, T., Prenen, J., Nilius, B., Kuehn, E.W., and Walz, G. (2008). TRPP2 and TRPV4 form a polymodal sensory channel complex. J Cell Biol 182, 437-447.

Koulen, P., Cai, Y., Geng, L., Maeda, Y., Nishimura, S., Witzgall, R., Ehrlich, B.E., and Somlo, S. (2002). Polycystin-2 is an intracellular calcium release channel. Nat Cell Biol 4, 191-197.

Li, Y., Wright, J.M., Qian, F., Germino, G.G., and Guggino, W.B. (2005). Polycystin 2 interacts with type I inositol 1,4,5-trisphosphate receptor to modulate intracellular $\mathrm{Ca}^{2+}$ signaling. J Biol Chem 280, $41298-41306$.

Maruyama, T., Kanaji, T., Nakade, S., Kanno, T., and Mikoshiba, K. (1997). 2APB, 2-aminoethoxydiphenyl borate, a membrane-penetrable modulator of Ins(1,4,5)P3-induced $\mathrm{Ca}^{2+}$ release. J Biochem 122, 498-505.

Mochizuki, T., Wu, G., Hayashi, T., Xenophontos, S.L., Veldhuisen, B., Saris, J.J., Reynolds, D.M., Cai, Y., Gabow, P.A., Pierides, A., Kimberling, W.J., Breuning, M.H., Deltas, C.C., Peters, D.J., and Somlo, S. (1996). PKD2, a gene for polycystic kidney disease that encodes an integral membrane protein. Science 272, 1339-1342.

Montell, C. (2005). The TRP superfamily of cation channels. Sci STKE 2005, re3.

Moran, M.M., McAlexander, M.A., Biro, T., and Szallasi, A. (2011). Transient receptor potential channels as therapeutic targets. Nat Rev Drug Discov 10, 601-620.

Narayanan, D., Bulley, S., Leo, M.D., Burris, S.K., Gabrick, K.S., Boop, F.A., and Jaggar, J.H. (2013). Smooth muscle cell transient receptor potential polycystin-2 (TRPP2) channels contribute to the myogenic response in cerebral arteries. J Physiol 591, 5031-5046.

Nilius, B., and Owsianik, G. (2010). Transient receptor potential channelopathies. Pflugers Arch 460, 437-450.

Noble, F., Wank, S.A., Crawley, J.N., Bradwejn, J., Seroogy, K.B., Hamon, M., and Roques, B.P. (1999). International Union of Pharmacology. XXI. Structure, distribution, and functions of cholecystokinin receptors. Pharmacol Rev 51, 745-781.

Pacaud, P., and Bolton, T.B. (1991). Relation between muscarinic receptor cationic current and internal calcium in guinea-pig jejunal smooth muscle cells. J Physiol 441, 477-499.

Pan, Z., Yang, H., and Reinach, P.S. (2011). Transient receptor potential (TRP) gene superfamily encoding cation channels. Hum Genomics 5, $108-116$

Sammels, E., Devogelaere, B., Mekahli, D., Bultynck, G., Missiaen, L., Parys, J.B., Cai, Y., Somlo, S., and De Smedt, H. (2010). Polycystin-2 activation by inositol 1,4,5-trisphosphate-induced $\mathrm{Ca}^{2+}$ release requires its direct association with the inositol 1,4,5-trisphosphate receptor in a signaling microdomain. J Biol Chem 285, 18794-18805.

Shen, B., Cheng, K.T., Leung, Y.K., Kwok, Y.C., Kwan, H.Y., Wong, C.O., Chen, Z.Y., Huang, Y., and Yao, X. (2008). Epinephrine-induced $\mathrm{Ca}^{2+}$ influx in vascular endothelial cells is mediated by CNGA2 channels. J Mol Cell Cardiol 45, 437-445.

Sours-Brothers, S., Ding, M., Graham, S., and Ma, R. (2009). Interaction between TRPC1/TRPC4 assembly and STIM1 contributes to store-operated $\mathrm{Ca}^{2+}$ entry in mesangial cells. Exp Biol Med (Maywood) 234, 673-682.

Spirli, C., Locatelli, L., Fiorotto, R., Morell, C.M., Fabris, L., Pozzan, T., and Strazzabosco, M. (2012). Altered store operated calcium entry increases cyclic 3',5'-adenosine monophosphate production and extracellular signal-regulated kinases 1 and 2 phosphorylation in polycystin-2-defective cholangiocytes. Hepatology 55, 856-868.

Suzuki, S., Takiguchi, S., Sato, N., Kanai, S., Kawanami, T., Yoshida, Y., Miyasaka, K., Takata, Y., Funakoshi, A., and Noda, T. (2001). Importance of CCK-A receptor for gallbladder contraction and pancreatic secretion: a study in CCK-A receptor knockout mice. Jpn J Physiol 51, 585-590.

Tsiokas, L. (2009). Function and regulation of TRPP2 at the plasma membrane. Am J Physiol Renal Physiol 297, F1-F9.

Tsiokas, L., Kim, E., Arnould, T., Sukhatme, V.P., and Walz, G. (1997). Homo- and heterodimeric interactions between the gene products of PKD1 and PKD2. Proc Natl Acad Sci USA 94, 6965-6970.

Tsvilovskyy, V.V., Zholos, A.V., Aberle, T., Philipp, S.E., Dietrich, A., Zhu, M.X., Birnbaumer, L., Freichel, M., and Flockerzi, V. (2009). Deletion of TRPC4 and TRPC6 in mice impairs smooth muscle contraction and intestinal motility in vivo. Gastroenterology 137 , 1415-1424.

Venkatachalam, K., and Montell, C. (2007). TRP channels. Annu Rev Biochem 76, 387-417.

Vennekens, R., Menigoz, A., and Nilius, B. (2012). TRPs in the Brain. Rev Physiol Biochem Pharmacol 163, 27-64.

Wu, L.J., Sweet, T.B., and Clapham, D.E. (2010). International Union of Basic and Clinical Pharmacology. LXXVI. Current progress in the mammalian TRP ion channel family. Pharmacol Rev 62, 381-404.

Zhang, D.X., and Gutterman, D.D. (2011). Transient receptor potential channel activation and endothelium-dependent dilation in the systemic circulation. J Cardiovasc Pharmacol 57, 133-139.

Zhao, R., Zhou, M., Li, J., Wang, X., Su, K., Hu, J., Ye, Y., Zhu, J., Zhang, G., Wang, K., Du, J., Wang, L., and Shen, B. (2015). Increased TRPP2 expression in vascular smooth muscle cells from high-salt intake hypertensive rats: The crucial role in vascular dysfunction. Mol Nutr Food Res 59, 365-372.

Open Access This article is distributed under the terms of the Creative Commons Attribution License which permits any use, distribution, and reproduction in any medium, provided the original author(s) and source are credited. 